\title{
Determinan Sikap Dalam Penggunaan Sistem Keuangan Desa (Siskeudes)
}

\author{
Dinda Amelia Kusumastuti ${ }^{1}$, Rihan Mustafa Zahri ${ }^{2)}$ \\ ${ }^{1}$ Prodi Akuntansi, Universitas PGRI Madiun, Indonesia. \\ email: dindakusumastuti@gmail.com \\ ${ }^{2}$ Prodi Manajemen Pajak, Universitas PGRI Madiun, Indonesia. \\ email: Rihanmustafa@unipma.ac.id
}

\begin{abstract}
SISKEUDES application is an application developed by BPKP to improve the quality of village financial governance that must be implemented. The implementation of regulations, the success of the purpose of the application of SISKEUDES will determine the effectiveness of the system. The successful implementation of the system is seen from the attitude of the village government in using the system. This research aims to test the perception of usability, perception of ease of use, subjective norms, and complementary to the attitude of use of rural financial system (SISKEUDES) applications. This study used survey methods and took samples in the village government of Madiun Regency and Kediri Regency which positioned as users of SISKEUDES application as many as 230 respondents. Data that has been disseminated through questionnaires is analyzed using partial least square (PLS) based structural models with SmartPLS software version 2.0. The results of this study prove that the user attitude of SISKEUDES application is positively influenced by perception of usability, subjective norms, and compatibility in using SISKEUDES applications. The study found the perception of ease of use had no effect on the attitudes of SISKEUDES application users.
\end{abstract}

Keywords: Perception of Usability, Perception of Ease of Use, Subjective Norms, Compatibility, Attitude.

\begin{abstract}
Abstrak
Aplikasi SISKEUDES merupakan aplikasi yang dikembangkan BPKP untuk meningkatkan kualitas tata kelola keuangan desa yang wajib diterapkan. Adanya peraturan yang wajib diterapkan, keberhasilan dari tujuan diterapkannya aplikasi SISKEUDES akan menentukan efektivitas dari sistem tersebut. Keberhasilan penerapan sistem tersebut dilihat dari sikap pemerintah desa dalam menggunakan sistem. Penelitian ini bertujuan untuk menguji persepsi kegunaan, persepsi kemudahan penggunaan, norma subjektif, dan kompatabilitas terhadap sikap penggunaan aplikasi Sistem Keuangan Desa (SISKEUDES). Penelitian ini menggunakan metode survei dan mengambil sampel pada pemerintah desa Kabupaten Madiun dan Kabupaten Kediri yang berposisi sebagai pengguna aplikasi SISKEUDES sebanyak 230 responden. Data yang sudah disebar melalui kuesioner dianalisis menggunakan model struktural berbasis Partial Least Square (PLS) dengan software SmartPLS versi 2.0. Hasil penelitian ini membuktikan bahwa sikap pengguna aplikasi SISKEUDES dipengaruhi secara positif oleh persepsi kegunaan, norma subjektif, dan kompatabilitas dalam menggunakan aplikasi SISKEUDES. Penelitian ini menemukan persepsi kemudahan penggunaan tidak berpengaruh terhadap sikap pengguna aplikasi SISKEUDES. Kata Kunci: Persepsi Kegunaan, Persepsi Kemudahan Penggunaan, Norma Subjektif, Kompatabilitas, Sikap.
\end{abstract}

\section{PENDAHULUAN}

Perkembangan teknologi yang semakin maju saat ini berguna untuk mempermudah dan mempercepat pekerjaan manusia. Menurut Damasiotis et. al., 2015, teknologi informasi adalah penggunaan perangkat software dan hardware untuk mengelola informasi yang disebut sebagai sistem informasi. Sistem informasi merupakan prosedur pengumpulan data-data yang diolah menjadi informasi untuk disampaikan kepada para penggunanya (Romney dan Steinbart, 2015: 7). Teknologi informasi sangat bermanfaat bagi organisasi, khususnya pada organisasi pemerintahan untuk menjalankan kegiatan yang lebih efektif dan efisien. Selain itu, dalam organisasi pemerintahan teknologi informasi diterapkan sebagai alat perencanaan, kontrol dan dapat membantu dalam pengambilan keputusan organisasi. 
Penerapan teknologi informasi di organisasi pemerintahan, salah satunya adalah pemerintah desa akan membantu memberikan pelayanan publik yang transparan dan akuntabel. Pemerintah desa harus menerapkan prinsip akuntabilitas dalam mengelola keuangan desa karena mengingat pemberian dana ke desa yang begitu besar. Dalam mewujudkan tata kelola pemerintah desa yang baik (Good Village Governance) diperlukan sarana pendukung dan sumber daya manusia yang berkompeten serta teknologi informasi yang memadai dan dapat diandalkan.

Kendala pemerintah desa saat ini belum mempunyai prosedur dalam mengelola keuangan desa dan belum kritisnya masyarakat desa atas pengelolaan anggaran desa, sehingga banyak terjadi tindak penyelewangan oleh pemerintah desa dalam menggunakan dana desa (bpkp.go.id, diakses pada bulan Januari 2018). Dalam mengurangi kasus korupsi oleh pemerintah desa, Badan Pengawasan Keuangan dan Pembangunan (BPKP) mengeluarkan aplikasi Sistem Keuangan Desa (SISKEUDES). Aplikasi SISKEUDES adalah aplikasi yang dikembangkan BPKP untuk meningkatkan kualitas pengelolaan keuangan desa. Fitur-fitur yang terdapat dalam aplikasi SISKEUDES dibuat sederhana dan user friendly sehingga memudahkan pengguna dalam mengoperasikan aplikasi. Proses penginputan sekali sesuai transaksi yang ada, dapat menghasilkan output berupa dokumen penatausahaan dan laporanlaporan yang sesuai dengan ketentuan peraturan undang-undang (bpkp.go.id, diakses pada bulan Januari 2018).

Aplikasi SISKEUDES dikembangkan karena adanya penerapan UU Nomor 6 Tahun 2014. Pemerintah desa diberi wewenang untuk mengelola keuangan sendiri sesuai UU tentang desa pada pasal 72, seperti mengelola keuangan yang berasal dari Pendapatan Asli Desa (PAD) dan Pendapatan Transfer lainnya yang berupa Alokasi Dana Desa (ADD). ADD meliputi bagian dari hasil pajak, retribusi Kabupaten/Kota dan bantuan keuangan dari APBD Provinsi/Kabupaten/Kota (bpkp.go.id, diakses pada bulan Januari 2018). Dengan adanya hal itu, pemerintah desa harus menerapkan prinsip akuntabilitas dan transparansi karena dituntut untuk membuat laporan. Laporan tersebut ditujukan kepada Bupati/Walikota dan Badan Permusyawaratan Desa (BPD) mengenai laporan yang terkait keuangan desa (bpkp.go.id, diakses pada bulan Januari 2018).

Pada tahun 2016, Pemerintah Kabupaten Madiun dan Kabupaten Kediri telah melakukan sosialisasi dan launching aplikasi SISKEUDES kepada seluruh Kepala Desa. Selanjutnya, ditindaklanjuti berupa bimbingan teknis secara bertahap dan berkesinambungan kepada satuan petugas Kecamatan, operator Desa, dan pejabat yang menangani pengelolaan keuangan Desa. Aplikasi SISKEUDES wajib diimplementasikan pada tahun 2017 dalam versi offline. Dalam berbasis online di Kabupaten Madiun dan Kabupaten Kediri dilaksanakan pada akhir tahun 2017. Upaya ini merupakan salah satu wujud komitmen Pemerintah Daerah dalam pengawasan pengelolaan keuangan Desa. Inovasi Pemerintah Daerah diharapkan dapat mewujudkan pengelolaan keuangan Desa yang terintegrasi dengan baik. Hal itu sesuai dengan mekanisme kerja tahunan Pemerintah Desa berdasarkan regulasi yang berlaku dengan asas transparan, akuntabel, partisipatif, tertib, dan disiplin anggaran (Madiunkab.go.id, diakses pada bulan Januari 2018).

Penggunaan sistem informasi pada pemerintah desa bersifat wajib (UU Nomor 6 Tahun 2014) sehingga seluruh desa harus menggunakan sistem yang telah ditetapkan. Dengan adanya peraturan yang wajib, penerapan sistem tersebut dapat dilihat dari sikap pemerintah desa dalam menggunakan SISKEUDES. Penelitian ini terkait dengan aspek keperilakuan, sehingga menggunakan teori penerimaan teknologi atau yang dikenal sebagai teori TAM (Technology Acceptance Model) yang dikenalkan pertama kali oleh Davis F., Richard P., dan Warshaw P. (1989). Teori TAM menjelaskan bahwa sikap individu didefinisikan oleh Davis et. al. (1989) sebagai perasaan positif atau negatif dari seseorang jika harus menggunakan sistem yang akan 
ditentukan. Tidak secara langsung muncul informasi terkait alasan individu menggunakan sistem tertentu. Akan tetapi, terdapat penyebab munculnya dari adanya sikap individu.

Dengan demikian, peneliti ingin mengetahui sikap positif atau negatif pemerintah desa dalam menggunakan sistem tersebut, karena sebelumnya pemerintah desa dalam mengelola keuangan desa dengan cara manual. Proses transisi dari manual ke penggunaan teknologi (dari offline ke online) tentunya akan berdampak pada sikap individu dalam menggunakan aplikasi SISKEUDES. Penelitian yang terkait perilaku penggunaan sistem informasi yang menggunakan teori TAM yaitu: Jan dan Contreras (2011), Budiman dan Arza (2013), Iswahyudi (2017), Imran et. al. (2014).

\section{LANDASAN TEORI DAN PENGEMBANGAN HIPOTESA}

Konsep Dasar Sistem Informasi Keperilakuan

Sistem informasi keperilakuan mempelajari bagaimana suatu organisasi dapat mengembangkan sistem teknologi informasi untuk mengarahkan perilaku-perilaku seseorang dalam berinteraksi dengan sistem teknologi informasi untuk membantu tujuan organisasi (Hartono, 2007:3). Sejak tahun 1980, penelitian tentang sistem informasi telah mencoba mempelajari perilaku mengapa dan bagaimana seseorang menggunakan sistem teknologi informasi.

\section{Aplikasi Sistem Keuangan Desa (SISKEUDES)}

SISKEUDES adalah aplikasi yang dikembangkan Badan Pengawasan Keuangan dan Pembangunan (BPKP) dalam rangka meningkatkan kualitas tata kelola keuangan desa. Tujuan diterapkannya aplikasi SISKEUDES akan membantu pemerintah desa untuk mengelola keuangan desa berdasarkan prinsip pengelolaan keuangan yaitu transparan, akuntabel, efisien, dan efektif. Proses penginputan sekali sesuai dengan transaksi yang ada, dapat menghasilkan output berupa dokumen penatausahaan dan laporan-laporan yang sesuai di ketentuan perundang-undangan.

\section{Teori TAM (Technology Acceptance Model)}

Model penerimaan teknologi adalah salah satu teori mengenai penggunaan sistem teknologi informasi yang sering digunakan untuk menjelaskan penerimaan individu terhadap penggunaan sistem teknologi informasi. Model penerimaan teknologi pertama kali dikenalkan oleh Davis et. al. (1989) dengan teori yang bernama Technology Acceptance Model (TAM). Persepsi kegunaan diartikan sebagai individu percaya bahwa menggunakan suatu teknologi akan meningkatkan kinerjanya. Persepsi kemudahan penggunaan diartikan sebagai individu percaya bahwa menggunakan suatu teknologi akan bebas dari usaha dengan artian lain bahwa menggunakan sistem teknologi tidak menyulitkan pekerjaan individu (Hartono, 2007: 114115). Menurut Davis et. al. (1989) sikap terhadap perilaku diartikan sebagai perasaan negatif atau positif dari individu jika harus melakukan perilaku yang akan ditentukan. Mathieson (1991) mengatakan bahwa sikap terhadap perilaku sebagai evaluasi pemakai tentang ketertarikannya menggunakan sistem. Niat perilaku menurut Hartono (2007:116) suatu kemauan atau keinginan individu untuk melakukan suatu perilaku tertentu. Penggunaan yang sesungguhnya (actual use) apabila dikaitkan dengan penggunaan teknologi, maka dapat diketahui informasi terkait keberhasilan atau kegagalan dalam menerapkan teknologi informasi tersebut. 


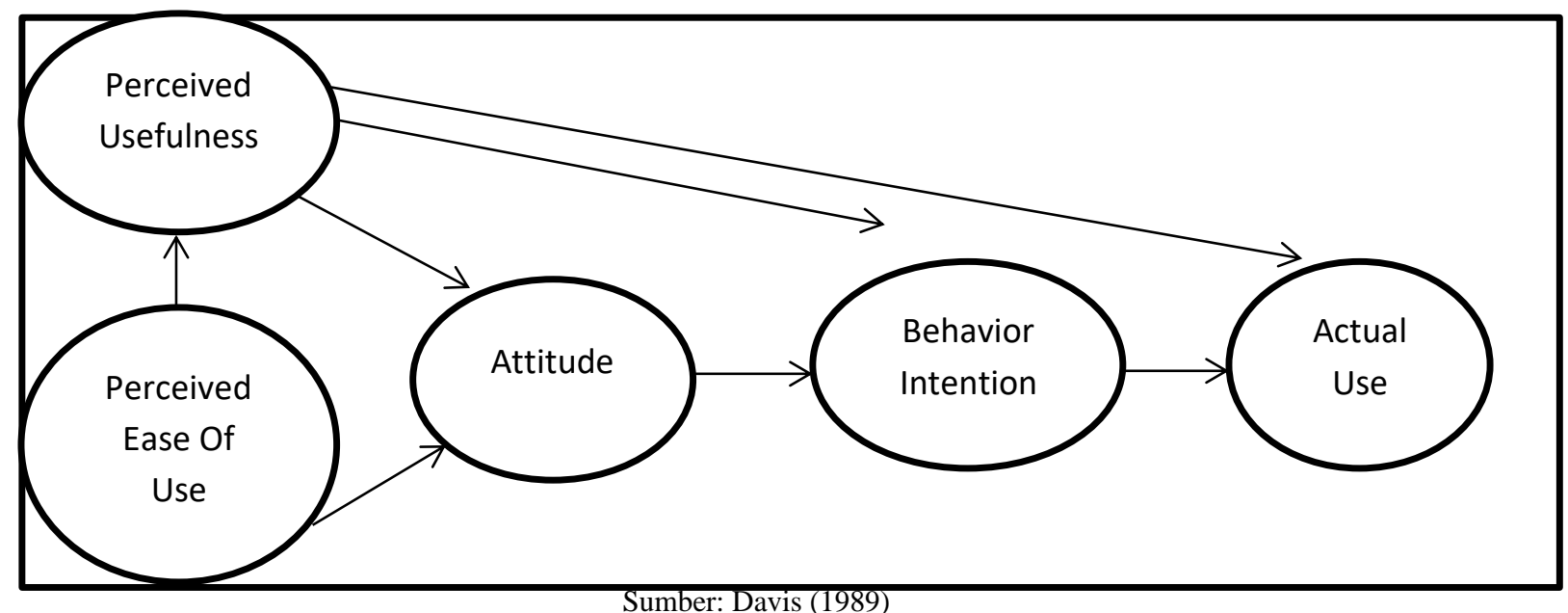

Gambar 1. Model Technology Acceptance Model (TAM)

\section{Pengembangan Teori TAM (Technology Acceptance Model)}

Model baru TAM yang dibangun dari elaborasi dari hasil-hasil penelitian sebelumnya yang sudah menemukan banyak variabel-variabel lain yang mempengaruhi konstruk persepsi kegunaan, persepsi kemudahan penggunaan, sikap, niat pengguna dan perilaku pengguna atau actual use (Hartono, 2007:127). Variabel lain dari pengembangan model TAM pada penelitian ini adalah norma subjektif dan kompatabilitas. Menurut Hartono, (2007:42) norma subjektif adalah persepsi atau pandangan seseorang terhadap kepercayaan-kepercayaan orang lain yang akan mempengaruhi niat untuk melakukan atau tidak melakukan perilaku yang sedang dipertimbangkan.

Penelitian terdahulu mengenai penggunaan teknologi informasi yang menggunakan variabel norma subjektif yaitu Malhotra dan Galetta (1999) menurutnya penting untuk mempertimbangkan norma subjektif karena konstruk yang menunjukkan pengaruh sosial terhadap penggunaan teknologi informasi. Penelitian terdahulu mengenai penggunaan teknologi informasi yang menggunakan variabel kompatabilitas yaitu Rogers (1983). Rogers (1983) mendefinisikan kompatabilitas sebagai tingkat dimana penggunaan inovasi dirasakan oleh individu sebagai konsisten dengan nilai sosial dan kecocokan. Apabila dikaitkan dengan penelitian ini adalah kecocokan pemerintah desa dalam menggunakan aplikasi SISKEUDES menjadi kebutuhan dan gaya bekerja pemerintah desa dalam mengerjakan tugasnya sehingga pekerjaan menjadi lebih efisien dan efektif.

\section{KERANGKA KONSEPTUAL DAN PENGEMBANGAN HIPOTESIS}

Penelitian ini dilakukan untuk menguji faktor-faktor yang mempengaruhi sikap pengguna aplikasi SISKEUDES pada pemerintah Desa di Kabupaten Madiun dan Kabupaten Kediri. Fenomena penelitian ini adalah adanya penerapan aplikasi SISKEUDES pada pemerintah desa yang semula menerapkan berbasis offline menjadi berbasis online. Konstruk yang digunakan pada penelitian ini adalah persepsi kegunaan, persepsi kemudahan penggunaan, norma subjektif, kompatabilitas terhadap sikap pemerintah desa dalam menggunakan aplikasi SISKEUDES. Berikut ini adalah model penelitian yang akan digunakan: 


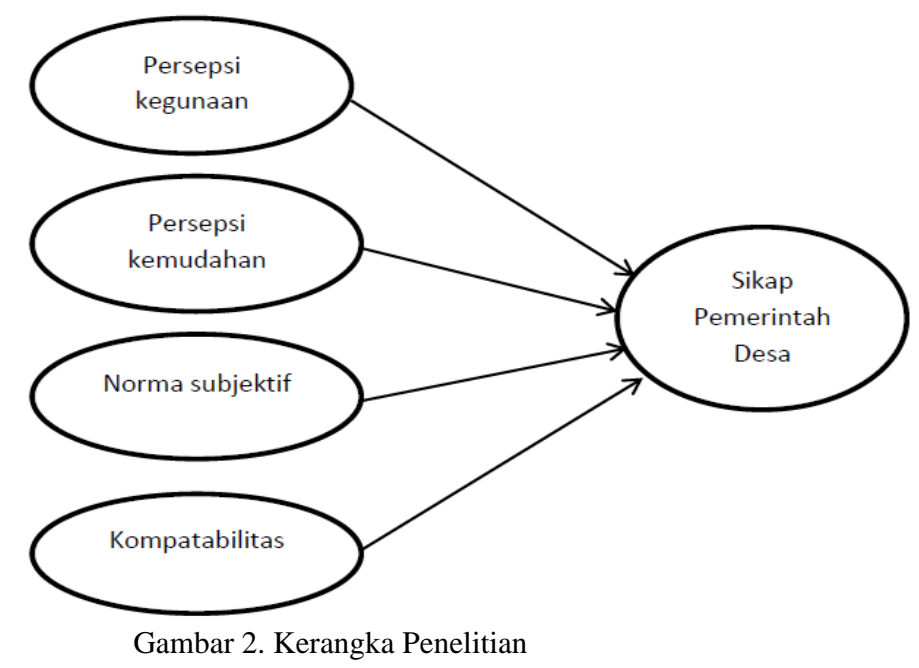

Penelitian ini mempunyai empat hipotesis penelitian yang menunjukkan pengujian pengaruh dari setiap konstruk terhadap sikap pengguna aplikasi SISKEUDES. Hipotesis yang digunakan akan dijelaskan di bawah ini:

\section{Pengaruh Persepsi Kegunaan Terhadap Sikap}

Persepsi kegunaan dalam penelitian ini diartikan sebagai tingkat kepercayaan pemerintah desa bahwa aplikasi SISKEUDES akan berguna dan menjadi fasilitas dalam mengelola keuangan desa. Beberapa penelitian telah menjelaskan bahwa terdapat pengaruh positif antara persepsi kegunaan dan sikap dalam menggunakan teknologi informasi yaitu Davis et. al. (1989), Iswahyudi (2017), Chau et. al. (2001), Lin (2007), Jan dan Contreras (2011), Budiman (2013). Rumusan hipotesis berdasarkan uraian tersebut adalah:

H1: Persepsi kegunaan berpengaruh positif terhadap sikap pemerintah desa dalam menggunakan aplikasi SISKEUDES.

\section{Pengaruh Persepsi Kemudahan Terhadap Sikap}

Persepsi kemudahan dalam penelitian ini diartikan sebagai keyakinan pemerintah desa bahwa dengan menggunakan aplikasi SISKEUDES tidaklah hal yang sulit dan dalam penggunaannya tidak membutuhkan usaha yang keras. Beberapa penelitian sebelumnya bahwa persepsi kemudahan penggunaan berpengaruh positif terhadap sikap untuk menggunakan teknologi informasi diantaranya yaitu Davis et. al. (1989), Ayeh et. al. (2013), Pratiwi (2015), Chau et. al. (2001), Budiman (2013). Rumusan hipotesis berdasarkan uraian tersebut adalah:

H2: Persepsi kemudahan berpengaruh positif terhadap sikap pemerintah desa dalam menggunakan aplikasi SISKEUDES.

\section{Pengaruh Norma Subjektif Terhadap Sikap}

Dalam penelitian ini norma subjektif didefinisikan sebagai pengaruh dari Kepala Daerah, Kepala Desa dan rekan kerja untuk menggunakan aplikasi SISKEUDES. Penelitian terdahulu mengenai norma subjektif yang dilakukan oleh Jan dan Contreras (2011) dan Lu T., Shaio Y., dan Pang Y. (2010) membuktikan bahwa norma subjektif berpengaruh positif terhadap sikap. Rumusan hipotesis berdasarkan uraian tersebut adalah:

H3: Norma subjektif berpengaruh positif terhadap sikap pemerintah desa dalam menggunakan aplikasi SISKEUDES.

\section{Pengaruh Kompatabilitas Terhadap Sikap}

Dalam penelitian ini kompatabilitas diartikan sejauhmana aplikasi SISKEUDES dianggap sesuai atau cocok dengan kebutuhan pemerintah desa untuk memfasilitasi pekerjaannya dalam mengelola keuangan desa. Penelitian sebelumnya yang melakukan pengujian kompatabilitas terhadap sikap yaitu Amaro dan Duarte (2015), Chau et. al. (2001), 
Agag dan El-Masry (2016), Cho (2006) yang membuktikan bahwa kompatabilitas berpengaruh positif terhadap sikap pengguna sistem. Rumusan hipotesis berdasarkan uraian tersebut adalah:

H4: Kompatabilitas berpengaruh positif terhadap sikap pemerintah desa dalam menggunakan aplikasi SISKEUDES.

\section{METODE PENELITIAN}

Penentuan sampel dalam penelitian ini dilakukan dengan prosedur penyampelan probabilitas. Dalam prosedur penyampelan probabilitas, peneliti menggunakan teknik penyampelan acak sederhana (simple random sampling). Simple random sampling merupakan pengambilan sejumlah sampel dari suatu populasi secara acak tanpa ada aturan tertentu untuk memilih (Abdillah dan Hartono, 2015:62). Penentuan jumlah sampel pada populasi di kabupaten Madiun dan Kabupaten Kediri dengan menggunakan rumus slovin dengan nilai $\alpha$ sebesar 5\%. Perhitungan jumlah sampel penelitian dengan menggunakan rumus slovin diperoleh sebesar 230 sampel.

Setelah mengetahui jumlah sampel yang akan diteliti, peneliti menentukan responden yaitu satu desa diwakili dengan satu responden. Responden dalam penelitian ini adalah pegawai pemerintah desa yang berposisi sebagai pengguna aplikasi SISKEUDES di Kabupaten Madiun dan Kabupaten Kediri. Peneliti memilih responden tersebut karena pengguna aplikasi SISKEUDES merupakan seseorang yang memiliki pengaruh besar dalam penggunaan sistem aplikasi SISKEUDES. Teknik pengumpulan data menggunakan data survei. Data diperoleh dengan memberikan kuesioner kepada responden. Model SEM yang digunakan dalam penelitian ini yaitu Partial Least Square (PLS). Analisis data menggunakan bantuan aplikasi software SmartPLS versi 2.0 M3.

\section{HASIL DAN PEMBAHASAN}

\section{Pengujian Model Pengukuran (Outer Model)}

Uji outer model dilakukan dengan tiga tahapan yaitu, pengujian terhadap validitas konvergen, pengujian terhadap validitas diskriminan, dan pengujian terhadap reliabilitas.

1. Validitas Konvergen

Parameter yang digunakan dalam uji validitas konvergen adalah nilai AVE lebih dari 0,5 dan nilai cross loading lebih dari 0,7. Nilai AVE pada penelitian ini dapat dilihat pada tabel dibawah ini:

Tabel 1. Nilai AVE (Hasil Uji Validitas Konvergen)

\begin{tabular}{lc}
\hline \multicolumn{1}{c}{ Konstruk } & AVE \\
\hline Persepsi Kegunaan & 0,8052 \\
Persepsi Kemudahan Penggunaan & 0,5385 \\
Norma Subjektif & 0,6783 \\
Kompatabilitas & 0,6679 \\
Sikap & 0,5332 \\
\hline
\end{tabular}

Sumber: Data Primer Diolah (2018)

Nilai AVE dalam penelitian ini lebih dari 0,5 pada konstruk persepsi kegunaan, persepsi kemudahan penggunaan, norma subjektif, kompatabilitas, dan sikap. Dapat disimpulkan bahwa konstruk dan indikator yang digunakan dalam penelitian ini telah memenuhi uji validitas konvergen.

2. Validitas Diskriminan

Setelah dilakukan uji validitas konvergen, tahap selanjutnya adalah melakukan uji validitas diskriminan. Nilai akar AVE harus lebih dari 0,7 dalam satu variabel (Abdillah dan Hartono, 2015: 196). Nilai akar AVE dan korelasi variabel laten dapat dilihat pada Tabel 2 sebagai berikut: 
Tabel 2. Nilai Akar AVE dan Korelasi Variabel Laten (Hasil Uji Validitas Diskriminan)

\begin{tabular}{|c|c|c|c|c|c|c|c|c|}
\hline & $\begin{array}{l}\text { Akar } \\
\text { AVE }\end{array}$ & PKG & PKP & NS & KPTB & KPC & SKP & EFT \\
\hline PKG1 & 0,897329 & 1 & 0 & 0 & 0 & 0 & 0 & 0 \\
\hline PKP2 & 0,733826 & 0,1844 & 1 & 0 & 0 & 0 & 0 & 0 \\
\hline NS3 & 0,82359 & 0,4486 & 0,085 & 1 & 0 & 0 & 0 & 0 \\
\hline KPTB4 & 0,817251 & 0,312 & 0,3647 & 0,2731 & 1 & 0 & 0 & 0 \\
\hline SKP6 & 0,730205 & 0,386 & 0,6003 & 0,3832 & 0,3214 & 0,3388 & 1 & 0 \\
\hline
\end{tabular}

Sumber: Data Primer Diolah (2018)
Keterangan: PKG (Persepsi Kegunaan), PKP (Persepsi Kemudahan Penggunaan,
NS (Norma Subjektif), KPTB (Kompatabilitas), SKP (Sikap).

Berdasarkan Tabel 2 di atas dapat dilihat bahwa nilai akar AVE lebih besar dari korelasi variabel laten yaitu nilai akar AVE lebih dari 0,7 dalam satu variabel. Dengan demikian, dapat disimpulkan bahwa konstruk dan indikator yang digunakan dalam penelitian ini telah memenuhi uji validitas diskriminan.

3. Uji Reliabilitas

Uji reliabilitas pada penelitian ini menggunakan dua parameter, yaitu nilai cronbach's alpha yaitu lebih dari 0,6 dan nilai composite reliability yaitu lebih dari 0,7 . Nilai cronbach's alpha dan composite reliability dapat dilihat pada Tabel 3 sebagai berikut:

Tabel 3. Nilai Cronbach's Alpha dan Composite Reliability (Hasil Uji Reliabilitas)

\begin{tabular}{lcc}
\hline \multicolumn{1}{c}{ Konstruk } & Cronbach's Alpha & Composite Reliability \\
\hline PKG & 0,9206 & 0,9429 \\
PKP & 0,6858 & 0,8085 \\
NS & 0,8505 & 0,8934 \\
KPTB & 0,7512 & 0,8569 \\
SKP & 0,7105 & 0,8202
\end{tabular}

Sumber: Data Primer Diolah (2018)

Keterangan: PKG (Persepsi Kegunaan), PKP (Persepsi Kemudahan Penggunaan, NS (Norma Subjektif), KPTB (Kompatabilitas), SKP (Sikap).

Berdasarkan Tabel 3 dapat diketahui besarnya nilai cronbach's alpha yaitu lebih dari 0,6 dan besarnya composite reliability yaitu lebih dari 0,7 . Dari hasil tersebut maka dapat disimpulkan bahwa data dan hasil pengukuran yang dilakukan adalah reliabel.

Pengujian Model Struktural (Inner Model)

Setelah melakukan uji outer model, tahapan selanjutnya yang dilakukan adalah uji inner model. Pada tahap uji inner model ini menggunakan dua parameter pengukuran yaitu $\mathrm{R}^{2}$ dan path coefficient.

1. Nilai $\mathrm{R}^{2}$

Nilai $\mathrm{R}^{2}$ digunakan sebagai ukuran prosentase variansi konstruk endogen yang dapat dijelaskan oleh konstruk eksogen. Nilai $\mathrm{R}^{2}$ dapat dilihat pada Tabel 4 sebagai berikut:

Tabel 4. Nilai $\mathbf{R}^{2}$

\begin{tabular}{lc}
\hline Konstruk & $\mathbf{R}^{\mathbf{2}}$ \\
\hline Sikap & 0,132
\end{tabular}

Sumber: Data Primer Diolah (2018)

Berdasarkan Tabel 4 dapat diketahui bahwa nilai $\mathrm{R}^{2}$ pada konstruk sikap sebesar 0,132 artinya, presentase variansi konstruk sikap dapat dijelaskan oleh konstruk persepsi kegunaan, persepsi kemudahan penggunaan, norma subjektif, dan kompatabilitas sebesar 13,2\% sedangkan sisanya dijelaskan oleh konstruk lain diluar model. 


\section{Nilai Path Coefficient}

Nilai path coefficient menunjukkan tingkat signifikansi dalam pengujian hipotesis. Apabila nilai Path Coefficient yang ditunjukkan nilai $t$-statistic $>1,64$ maka hipotesis dalam penelitian ini diterima. Apabila nilai $t$-statistic $<1,64$ maka hipotesis dalam penelitian ini ditolak. Nilai $t$-statistic dapat dilihat pada Tabel 5.9 sebagai berikut:

Tabel 5. Nilai Path Coefficient

\begin{tabular}{|c|c|c|c|c|}
\hline Hipotesis & Konstruk & Original Sampel & t-statistic & Keputusan \\
\hline $\mathrm{H} 1$ & PKG $->$ SKP & 0,1448 & 3,6883 & Diterima \\
\hline $\mathrm{H} 2$ & $\mathrm{PKP} \quad->\mathrm{SKP}$ & $-0,0354$ & 0,5353 & Ditolak \\
\hline H3 & NS $\quad->$ SKP & 0,0776 & 2,0028 & Diterima \\
\hline $\mathrm{H} 4$ & KPTB -> SKP & 0,2177 & 4,2829 & Diterima \\
\hline
\end{tabular}

\footnotetext{
Sumber: Data Primer Diolah (2018)

Keterangan: PKG (Persepsi Kegunaan), PKP (Persepsi Kemudahan Penggunaan, NS (Norma Subjektif), KPTB (Kompatabilitas), SKP (Sikap).
}

Berdasarkan Tabel 5 hasil uji $t$-statistic sudah melebihi $>1,64$ pada variabel persepsi kegunaan, norma subjektif, kompatabilitas, dan sikap sehingga hipotesis diterima. Pada variabel persepsi kemudahan penggunaan hasil uji $t$-statistic $<1,64$ sehingga hipotesis ditolak. Berikut penjelasan mengenai hasil uji hipotesis pada penelitian ini.

\section{Pengaruh Persepsi Kegunaan Terhadap Sikap}

Hasil pengujian menunjukkan bahwa persepsi kegunaan berpengaruh positif terhadap sikap pengguna aplikasi SISKEUDES. Menurut hasil penelitian, semakin besar kegunaan yang ada pada aplikasi SISKEUDES untuk memfasilitasi pengelolaan keuangan desa maka sikap pengguna aplikasi SISKEUDES akan semakin baik untuk terus menggunakan aplikasi SISKEUDES. Dengan adanya menggunakan aplikasi tersebut dapat memfasilitasi Pemerintah Desa untuk mempermudah dan mempercepat dalam penyusunan pengelolaan keuangan desa karena tidak perlu menghitung secara manual. Hasil penelitian ini sejalan dengan penelitian yang dilakukan oleh Davis et. al. (1989), Iswahyudi (2017), Chau et. al. (2001), Lin (2007), Jan dan Contreras (2011), Budiman (2013) yang menyatakan bahwa persepsi kegunaan berpengaruh positif terhadap sikap pengguna sistem tertentu.

\section{Pengaruh Persepsi Kemudahan Penggunaan Terhadap Sikap}

Hasil pengujian menunjukkan bahwa persepsi kemudahan penggunaan tidak berpengaruh terhadap sikap pengguna aplikasi SISKEUDES. Menurut hasil penelitian, pengguna aplikasi SISKEUDES merasa sulit dan membutuhkan usaha yang keras dalam menggunakan aplikasi SISKEUDES maka sikap pengguna aplikasi SISKEUDES akan tetap menerima untuk menggunakan aplikasi tersebut karena penggunaannya bersifat wajib. Dengan adanya penggunaan aplikasi yang bersifat wajib, maka pengguna aplikasi SISKEUDES mengikuti bimbingan teknis yang diselenggarakan oleh pemerintah daerah agar dalam menggunakan aplikasi tidak merasa kesulitan.

Hasil penelitian ini berbeda dengan penelitian yang dilakukan oleh Davis et. al. (1989), Ayeh et. al. (2013), Pratiwi (2015), Chau et. al. (2001), Budiman (2013) yang menyatakan bahwa persepsi kemudahan penggunaan berpengaruh positif terhadap sikap pengguna sistem tertentu. Faktor yang mempengaruhi persepsi kemudahan terhadap sikap ditolak karena dipengaruhi oleh faktor usia. Rata-rata pengguna aplikasi SISKEUDES berusia lebih dari 45 tahun. Jadi, penguasaan dalam pengoperasian sistem teknologi masih kurang sehingga dalam bekerja meminta bantuan rekan kerjanya untuk mengajari penginputan data ke aplikasi SISKEUDES.

\section{Pengaruh Norma Subjektif Terhadap Sikap}

Hasil pengujian menunjukkan bahwa norma subjektif berpengaruh positif terhadap sikap pengguna aplikasi SISKEUDES. Menurut hasil penelitian, pengaruh lingkungan seperti Kepala Daerah, Kepala Desa, dan rekan kerja memengaruhi individu untuk menggunakan 
aplikasi SISKEUDES, maka sikap individu akan terus menggunakan aplikasi SISKEUDES untuk mengelola keuangan desa. Pengaruh tersebut memunculkan persepsi yang positif dari responden untuk menggunakan aplikasi SISKEUDES karena penerapan sistem yang wajib diterapkan. Hasil penelitian ini sejalan dengan penelitian yang dilakukan oleh Jan dan Contreras (2011) dan Lu T., Shaio Y., dan Pang Y. (2010) yang membuktikan bahwa norma subjektif berpengaruh positif terhadap sikap.

\section{Pengaruh Kompatabilitas Terhadap Sikap}

Hasil pengujian menunjukkan bahwa kompatabilitas berpengaruh positif terhadap sikap pengguna aplikasi SISKEUDES. Menurut hasil penelitian, semakin aplikasi SISKEUDES sesuai dengan cara kerja pengguna, maka akan semakin positif sikap pengguna terhadap aplikasi SISKEUDES. Kecocokan berkaitan dengan masa lalu pengguna aplikasi yang sebelumnya dilakukan secara offline kemudian berubah menjadi online tentu akan memberikan pengaruh positif terhadap sikap pengguna dalam menggunakan aplikasi SISKEUDES. Responden merasa cocok karena dalam menggunakan aplikasi tersebut dalam pengelolaan keuangan desa lebih cepat dan efisien dalam bekerja. Selain itu, kecocokan pemerintah desa menggunakan aplikasi SISKEUDES berbasis online dikarenakan pemerintah desa tidak perlu lagi datang ke kantor pemerintah daerah untuk memberikan laporan pertanggungjawaban keuangan desa karena aplikasi tersebut sudah terhubung dengan internet dan dapat dipantau langsung oleh pemerintah daerah atau pusat. Hasil penelitian ini sejalan dengan penelitian yang dilakukan Amaro dan Duarte (2015), Chau et. al. (2001), Agag dan El-Masry (2016), Cho (2006) yang membuktikan bahwa kompatabilitas berpengaruh positif terhadap sikap pengguna sistem.

\section{KESIMPULAN}

Penelitian ini membuktikan secara empiris pengaruh variabel yang terdapat dalam teori Technology Acceptance Model (TAM). Berdasarkan hasil pengujian hipotesis dapat disimpulkan bahwa persepsi kegunaan, norma subjektif, dan kompatabilitas berpengaruh terhadap sikap pemerintah desa. Namun, penelitian ini menemukan persepsi kemudahan penggunaan tidak memengaruhi sikap pemerintah desa dalam menggunakan aplikasi SISKEUDES.

Hasil penelitian tentang persepsi kegunaan terhadap sikap menunjukkan keyakinan pemerintah desa dengan menggunakan aplikasi SISKEUDES secara efisien akan memfasilitasi pekerjaannya sehingga akan memengaruhi sikap pemerintah desa untuk menggunakan aplikasi tersebut. Norma subjektif terhadap sikap menunjukkan tingkat kepercayaan pengguna aplikasi SISKEUDES dari pengaruh atasan seperti Kepala Daerah atau Kepala Desa serta rekan kerjanya sehingga akan memengaruhi sikap pemerintah desa untuk menggunakan aplikasi tersebut. Kompatabilitas terhadap sikap menunjukkan kesesuaian atau kecocokan pemerintah desa dalam menggunakan aplikasi SISKEUDES sehingga akan memengaruhi sikap pemerintah desa untuk menggunakan aplikasi tersebut.

Persepsi kemudahan penggunaan terhadap sikap menunjukkan bahwa pengguna aplikasi SISKEUDES merasa kesulitan dalam menggunakan aplikasi SISKEUDES karena rata-rata usia responden lebih dari 45 tahun. Jadi penguasaan dalam pengoperasian sistem teknologi masih kurang sehingga dalam bekerja masih meminta bantuan rekan kerjanya untuk mengajari penginputan data ke aplikasi. Pengguna aplikasi diharapkan mampu untuk mengoperasikan aplikasi SISKEUDES mulai dari perencanaan, pengelolaan keuangan desa sampai pembukuan. Di dalam aplikasi tersebut terdapat berbagai macam akun atau kode yang harus dipelajari terlebih dahulu dengan melihat parameter yang sudah ditentukan. Penginputan data tidak hanya satu atau dua langkah saja akan tetapi ada banyak langkah yang harus dilewati supaya data tersimpan dengan benar. 


\section{DAFTAR PUSTAKA}

Abdillah, W., dan Jogiyanto, H. 2015. Partial Least Square (PLS). Yogyakarta: C.V. Andi Offset.

Agag, G., dan El-Masry, A. 2016. Understanding Consumer Interntion to Participate in Online Travel Community and Effect Consumer Interntion to Purchase Travel Online and WOM: An Integration of Innovation Diffusion Theory and TAM with Trust. Elsevier. Computers in Human Behaviour. 60, 97-111.

Amaro, S., dan Duarte, P. 2015. An Integrative Model of Consumers Intentions to Purchase Travel Online. Elsevier. Tourism Management. 46, 64-79.

Ajzen, I. 1991. The Theory of Planned Behaviour. Organizational Behaviour and Human Decision Processes, 50(2), 179-211.

Ajzen, I. dan Fishbein,. M. 1975. Belief, Attitude, Intention and Behaviour: An Introduction to Theory and Research. Reading, Mass, Adisson-Wesley Pub. Co.

Ayeh, J.K., Norman., Rob L. 2013. Predicting The Intention To Use Consumer Generated Media For Travel Planning. Elsevier. Tourism Management. 35, 132-143.

Budiman, F. \& Arza I.F. 2013. Pendekatan Technology Acceptance Model Dalam Kesuksesan Implementasi Sistem Informasi Manajemen Daerah. Jurnal WRA, Vol. No. 1. H. 87110.

Chau P.Y.K. dan Paul, J.H. 2001. Information Technology Acceptance by Individual Professionals: A Model Comparison Approah. Decision Sciences. Vol. 32 (4), 699-719.

Cho, V. 2006. A Study Of The Roles Of Trusts and Risks In Information - Oriented Online Legal Services Using an Integrated Model. Information \& Management Vol. 43, 502520.

Damasiotis, Vyron, Panagiotis T., Illias S., Sotiris N.\& Evdokia T. 2015. IT Competences for Proffesional Accountants. A Review. Procedia-Social and Behavioral Sciences, 175 (2015) 537-55.

Davis F.D. 1989. Perceived Usefulness, Perceived Ease Of Use And User Acceptance Of Information Technology, MIS Quarterly. ABI/Inform Global. Management Science, Vol.13, No. 3, H. 319-340.

Davis F.D., Richard P. B., \& Warshaw P. R. 1989. User Acceptance of Computer Technology: A Comparison of Two Theoritical Models. ABI/Inform Global. Management Science, 982.

Hartono, Jogiyanto. 2007. Sistem Informasi Keperilakuan. Yogyakarta: C.V. Andi Offset.

http://www.bpkp.go.id/ diakses bulan Januari 2018.

http://www.madiunkab.go.id/ diakses bulan Januari 2018.

Imran, M., Darwanis \& Arfan M. 2014. "Pengaruh Kemudahan Penggunaan Sistem Kemanfaatan Sistem dan Keahlian Komputer Terhadap Efektivitas Sistem Pengelolaan Keuangan Daerah di Pemerintahan Kota Banda Aceh". Jurnal Magister Akuntansi Pascasarjana Universitas Syiah Kuala, Vol. 3, No. 4, H. 54-65.

Iswahyudi, M. 2017. "Determinan Sikap Pemerintah Desa Dalam Menggunakan Sistem EVillage Budgeting". Tesis. Program Magister Akuntansi Universitas Brawijaya: Malang.

Jan, Alberto Un., \& Contreras, Vilma. 2011. Technology Acceptance Model for The Use of Information Technology in Universities. Elsevier. Computers in Human Behaviour. 27, 845-851.

Lin. 2007. Predicting Consumer Intentions To Shop Online: an Empirical Test of Competing Theories. Journal of Electronic Commerce Research And Applications 6: 422-433.

Malhotra, Y., dan Galleta, D.F. 1999. Extending the Technology Acceptance Model to Account for Social Influence Theoritical Bases and Emirical Validation. Proceedings of the 32nd Hawaii International Conference on System Sciences. 1-11. 
Mathieson, K. 1991. Prediciting User Intentions: Comparing the Technology Acceptance Model With the Theory of Planned Behavior. Information Systems Researc. 2(3). 73191.

Pratiwi E. 2015. Determinan Minat dan Perilaku Nasabah Dalam Penggunaan Mobile Banking:

Satu Pendekatan Model Decomposed Theory of Planned Behaviour. Tesis. Program Magister Akuntansi Universitas Brawijaya: Malang.

Romney M.B. \& P.J Steinbart. 2015. Sistem Informasi Akuntansi, Edisi 13. Jakarta: Salemba Empat.

Undang-Undang Nomor 6 Tahun 2014 tentang Desa. 